\title{
Disclosure of the HIV Infection Diagnosis in the Context of Counseling from the Client's Perspective
}

\author{
Diva Maria Faleiros Camargo Moreno ${ }^{1}$ \\ São Paulo City Health Department, São Paulo, Brazil \\ Faculty of Public Health, University of São Paulo, São Paulo, Brasil \\ Alberto Olavo Advíncula Reis \\ Faculty of Public Health, University of São Paulo, São Paulo, Brasil
}

\begin{abstract}
The present study emerged from research done in two Testing and Counseling Centers (CTC) for STD/ AIDS in São Paulo. It aims at describing the reagent HIV test disclosure processes within the context of serological counseling. The study involved 14 subjects interviewed after their test results were disclosed. In the analysis and understanding of the counseling processes investigated, concepts from D. W. Winnicott's psychoanalytical theory were applied. The results showed that facing the HIV infection diagnosis and being willing to take care of one's health after the reagent result disclosure has different effects on subjects, depending on how the counseling takes place. On the one hand, they can have the opportunity to confront themselves, their own problems and the anguish generated by the result disclosure, observing more or less psychic integrity from the subjects. On the other hand, this was not observed in cases where the subjects did not feel welcome and supported during counseling. It is important that an intersubjective relationship of support be established at the moment of the reagent HIV result disclosure, so that counseling can fulfill its strategic function of focusing on the specific problem and the healthiest resources from the individual.
\end{abstract}

Keywords: Counseling, disclosure, psychoanalytical theory, HIV serodiagnosis.

\section{Revelação do Diagnóstico da Infecção pelo HIV no Contexto do Aconselhamento: A Versão do Usuário}

\section{Resumo}

A partir de uma investigação realizada em dois Centros de Testagem e Aconselhamento em DST/Aids de São Paulo, objetiva-se descrever processos de revelação do diagnóstico da infecção pelo HIV no contexto do aconselhamento sorológico. O estudo envolveu 14 sujeitos entrevistados após a revelação do resultado do teste. Conceitos da teoria psicanalítica de D. W. Winnicott foram utilizados para analisar e compreender os processos de aconselhamento investigados. Os resultados mostraram que o enfrentamento do diagnóstico da infecção pelo HIV e o desejo de cuidar da saúde a partir da revelação do resultado reagente têm efeitos variados nos sujeitos, dependendo do modo como o aconselhamento é feito. De um lado, pode-se ter a oportunidade de confronto consigo mesmo, com os próprios problemas, com a angústia gerada pela revelação do resultado, observando-se maior ou menor integridade psíquica dos sujeitos. Em contraste, isso não foi observado nos casos em que os sujeitos não se sentiram acolhidos e apoiados no aconselhamento. É importante que seja estabelecida uma relação intersubjetiva de ajuda no

Contact: E-mail: dmfcm@usp.bre albereis@usp.br 
momento da revelação do diagnóstico da infecção pelo HIV para que o aconselhamento possa cumprir sua função estratégica de focar no problema específico e nos recursos mais saudáveis do indivíduo.

Palavras-chave: Aconselhamento, revelação, teoria psicanalítica, sorodiagnóstico do HIV.

\section{La Revelación del Diagnóstico de la Infección por el VIH en el Contexto del Asesoramiento: La Versión del Usuario}

\section{Resumen}

A partir de una investigación que se realizó en Centros de Prueba y Asesoramiento en EST/Sida de São Paulo, el objetivo es el de describir procesos de revelación del diagnóstico de la infección por VIH en el contexto del asesoramiento serológico. El estudio involucró a 14 sujetos entrevistados después de la revelación del resultado el examen. Se utilizaron conceptos de la teoría psicoanalítica de D. W. Winnicott para analizar y comprender los procesos de asesoramiento investigados. Los resultados mostraron que enfrentar el diagnóstico de la infección por el VIH y el deseo de cuidar de la salud a partir de la revelación del resultado reactivo tiene una variedad de efectos en los sujetos, dependiendo de la forma en que se haga el asesoramiento. Por una parte, puede existir la oportunidad de confrontación consigo mismo, con sus propios problemas, con la angustia generada por la revelación del resultado, en que se observa mayor o menor integridad psíquica de los sujetos. Como contraste, eso no fue observado en los casos en que los sujetos no se sintieron acogidos y apoyados en la orientación. Es importante establecer una relación intersubjetiva de ayuda en el momento de revelar el diagnóstico de la infección por VIH, para que el asesoramiento pueda cumplir su función estratégica de enfocar el problema específico, y en los recursos más saludables del individuo

Palabras clave: Asesoramiento, revelación, teoría psicoanalítica, serodiagnóstico del VIH.

This study has the aim of describing processes to disclose the diagnosis of the HIV infection, in the context of serological counseling, based on the client' $\mathrm{s}^{2}$ version and using as a theoretical framework the analysis and psychoanalytic theory of D. W. Winnicott.

Building a counseling practice at the centers called Centers for Tests and Counseling (CTC) in present day STD/Aids in theory was supported by Carl Rogers. For the author,

... the effective psychological visit [counseling] consists in a permissive relationship, structured in a defined way, that allows the patient to reach an understanding of himself, to such a degree that it enables him to

2 In Brazilian-Portuguese the word is "usuário", meaning, "the clients served by the public health system" who should be understood as a holder of the Constitutional equal and universal right to access prevention and care, including medication and rehabilitation. progress, in light of this new guidance. (Rogers, 1974a, p. 29).

In official Brazilian documents, counseling is explained as being a technique proposed for work in HIV testing centers. In such documents, references to Roger's way of working can be found, as well as his theoretical conceptions surrounding this practice (Ministério da Saúde [MS], 1999a, 1999b).

Rogers (1974b) recommends the authentic or genuine attitude of the professional who takes on the task of offering counseling, pointing out that the aim of this practice is to help the person become whole, independent and mature enough to resolve his problems as they appear throughout life. The author bases himself on the principle that people potentially have this ability, and can resolve their own difficulties during the counseling process, as long as the adequate environment is offered to them (Rogers, 1974b).

To attain this goal, the counselor should seek to accept and understand the client's personality, 
with its positive and negative aspects, as there is that demand to come closer, to think jointly with the client (the clients served by the public health system). What is prioritized, therefore, in that counselor-client relationship, is the emotional content, overriding the intellectual content, and more than resolving a problem, enabling or empowering the client to take his own decisions in the present and the future. This becomes challenging in counseling for STD/HIV/Aids, as it presupposes that a certain amount of information will be transmitted, and despite this, that the client's focus will be maintained. Souza, Czeresnia and Natividade (2008) points out that this aspect of counseling makes it a paradoxical practice, in so far that it contains, from the client's viewpoint, moments that generate shelteringtension, dialogue-regulation or normativity; fear-motivation, reflection-paralysis.

In counseling for HIV/Aids, it is necessary to create the conditions to provide that listening attitude, respect the individual's system of belief, and contribute enabling them to trust their own internal resources to take decisions on their own lives. An additional task consists in everything that takes place in the context, relating to having or not having been infected by the $\mathrm{Hu}-$ man Immunodeficiency Virus (HIV), having or not the ability to adopt more protected sexual practices, being able or not to negotiate the use of condoms with a partner, wanting or not to take the antiretroviral medication, among other conditions in life, health and care that could relate to the uniqueness of the client participating in counseling.

Therefore,

... actions in counseling carried out within the context of the CTC allow for the possibility of transforming citizens into subjects of their own health and their disease. Based on their personal experience, counseling should allow them to integrate the information on Aids and prevention, and to find personal and collective alternatives to confront the issues set forth by the epidemic. (MS, 1999a, p. 9)

The counseling process in STD/Aids contains three components: emotional support to the client, educational support; and risk evaluation, leading to a possible reflection on values, attitudes and behaviors (Miranda, Barroso, Silva, \& Silva, 2008).

Thus, counseling can also be deemed to be an action in prevention, and is a component of the diagnostic process, providing individualized and unique attention to the client. The fulfillment of counseling, in the practice of CTC's, can be present during the moments of pre and post testing, and may not be restricted to servicing those people who seek a diagnosis (MS, 2010).

Counseling should be offered to all of the clients at the CTC's, before the testing itself. It is at that moment that counseling is carried out, the welcoming, the creation of a tie, raising the situations of vulnerability and guidance on the test. This is a procedure that the client's have chosen to follow or not, regardless of the diagnostic methodology used, be it the rapid or conventional one. In this case, a professional welcomes the client and speaks about the motivation for undergoing the test, the methodology that will be used and the expectations on the result. The client is entitled to deciding among the different test modalities offered at the CTC (MS, 2010).

All of these actions will only attain their goals by putting the client at the center, considering that person as someone autonomous, and taking into account the achievements of humanity in the field of human rights, especially sexual rights. In this field of knowledge, work has been carried out proposing an operational model that can be used as a tool by health professionals in their HIV prevention interventions (Paiva, 1998), and presenting an alternative and positive view of sexual rights, one guided by ethical principles and by enabling conditions, which involve: sexual diversity, the various ways of setting up a family, autonomy to make decisions and gender equality (Petchesky, 1999).

Counseling to disclose the HIV test (after test counseling) is a process in which the professional and the client share a situation, face to face, in which one holds the information the other is seeking, and where some space should be offered to sediment the knowledge that has been acquired during an entire lifetime of making one's own choices. The counselor has a 
role configured as being a sort of a moderator, a bearer of information that will be conveyed, attempting to guarantee an environment of reliability in the results, confidentiality and respect for individual rights.

In the initial conception of the CTC's, the creation of long lasting ties had not been foreseen in counseling processes, nevertheless, the number of encounters for counseling was left open. Presently, in accordance to the evolution of the epidemic, and faced with the complexity of the situations experienced by clients, what has been ever more valued is the tie with clients. Furthermore, the proposition is continued counseling for people who are awaiting the results of HIV, syphilis, hepatitis exams and for those who continue to live with HIV/Aids, carriers of hepatitis and their family members, while they are not referred to and serviced at the reference centers for treatment (MS, 2010).

The counseling dynamic will vary considerably, depending on the number of people involved, however, it is desirable that the counselor, when faced with the reagent result, be trained to: (a) offer emotional support, allowing the client some time to assimilate the impact of the diagnosis; deal with the feeling of guilt, rejection, punishment, demystifying aspects of degeneration, death, among others; (b) differentiate the condition of a carrier of the virus from that of disease, informing on the need for additional exams that will be carried out by a reference center, highlighting the importance of treatment for Aids; (c) reinforcing the need to adopt preventive measures to avoid re-infection by HIV and other STD's, and the transmission of the virus to others (d) guarantee learning in terms of how to use a condom; (e) orient on the need to disclose the result to the present-day partner(s), making available the center for that purpose; and (f) referral to additional medical assistance services, and social ones whenever necessary, motivating adherence to the medication therapy (MS, 1999a).

To comprehend the counseling processes analyzed in this article, concepts from D.W Winnicott's psychoanalytic theory were used. It is a theory based on the assumption that the intersubjective relationship between the analyst and the person undergoing analysis is what determines a subjective transformation, more than each of the participants in this duet (Winnicott, 1954/1978a).

When carrying out analytic work, the author proposes the creation of a setting to fulfill demands, that are transformed continuously in contemporary life, demanding a change in the analysts' stance. In his conception, in this setting, the priority is neither the position of the analyst nor the position of the one undergoing analysis, what is recommended is a position of transit between; a place where the individual can be provided with his pressing needs, without being invaded with content that he/she cannot bear, addressed by the analyst. The position proposed is that of a sufficiently good mother that offers her child the holding, that is, support for the fundamental anguish until the infant is able to use its own resources and walk on its own (Moreno \& Reis, 2002).

Winnicott (1971/1984, 1965/1994a), steadily identifying the importance of that first interview in psychoanalysis, developed a modality of attention called the therapeutic visit, geared especially to individuals for which a traditional therapy would not have been indicated. What was characterized at this(these) meeting(s) was valuing the time and space for conversation. In the therapeutic visit, what is proposed is that the environment created ease the presentation of issues brought by the individual, with the existence of support and the gradual appropriation of elucidation of these issues through that mutuality. This environment between the analyst and the one undergoing analysis is conceived based on notions developed and originating from the mother-infant relationship. The mother, in a special way, gradually introduces the infant in her relationship to people and objects, and in so far as is possible (Winnicott, 1971/1975b, $1951 / 1978 b$ ). The mother supports or sustains the child at the time in which she adapts to its psychic needs, during the process of maturing. Through this, she is constituting the holding of the infant, a notion which is representative of support itself. It means that all of the mother's 
attention is geared to the child, with a concern that brings her closer, in a way in which she can provide the necessary provision of ego functions that will be fundamental through the child's development. This holding is translated in the therapeutic relationship as the setting, that is, a reliable environment, a supportive one. Therefore, transferring the mother-child image to the analytic setting, and, by derivation, to the environment that exists for a relationship of trust, support and help, this is the role played, as a "sustaining presence", and that is deemed necessary at the moment of counseling, when disclosing the result of the ant-HIV test.

Winnicott (1986/2001) considers that one can only truly help someone when the interest for what this person says is kept alive. And it is that interest in the client that comes to seek the result of the anti-HIV test that we tried to research in the counseling process, for individuals heard in the survey that gave way to the present article.

\section{Method}

The research was carried out at two Centers for Tests and Counseling in STD/Aids in the Municipality of São Paulo (CTC), services where the counseling technology is practiced to disclose the result of the anti-HIV test. During the period in which the survey was carried out, the serological test used for the detection of HIV was the Immune-enzymatic Assay, known as the Elisa test, whose results were disclosed to the client approximately a fortnight after it was carried out. When the result was reagent, the Western Blot or Immunoblot confirmatory assays were carried out. At that time, there still did not exist the rapid test which is used nowadays at these centers, for the detection of an HIV infection.

The two CTC'S had similar characteristics when it comes to their operating hours and team composition. All of the counselors were of the female gender, and their professional training varied. There were physicians, nurses, social assistants, psychologists and educators in public health.
The institutions were informed on the objectives and procedures of the study at meetings with counselors and coordinators, prior to collecting the data. At these meetings, there existed an agreement regarding the strategy to indicate volunteers, and with respect to how to implement the interview for data collection, so as to interfere as little as possible in these professionals' routines.

The choice of these health units was based on their production data. Among the CTC's, these were the ones that most carried out the anti-HIV serological tests in the municipality, as they were located in sites with considerable circulation of people.

To be able to attract clients, posters were used and invitation-cards were made available for distribution by the counselors themselves at the end of each counseling.

One of the teams preferred to open up an agenda for the interviews, with pre-established schedules with the researcher, who would be advised when there was somebody interested in participating in the research. The other team preferred to orient the client to set up this contact personally with the researcher, to set up a time for the interview. This way of attracting clients did not attain the expected results, and after a few months, an agenda was opened at this unit, very similar to the work that was underway at the other CTC. Besides this strategy to attract interested people, the researcher began to appear at the CTC on dates and schedules agreed upon with the team, regardless of there being volunteers scheduled. This greater proximity with the institution made it possible to take the testimonies of clients immediately after counseling, whenever they were available; or schedule this for another day, as they wished.

Three testimonies were taken before the disclosure of the second serology (confirmatory exam). What was observed, in these cases, is that clients were able to express their perceptions on the way in which the result was communicated to them. However, two of them had the hope that the result of the second sample would not be reagent. One of the interviewees returned for the second interview, and it was possible to obtain 
information regarding the twos result disclosure processes experienced.

Another three interviewees were heard on the same day in which the second serology was disclosed, and in the three cases, this time did not seem to interfere in the way they formulated or gave their testimonies.

The open interview technique was used, defined as a "conversation between two, carried out under the initiative of the interviewer, destined to providing pertinent information for the object of the research, and centered (by the interviewer) on issues that were equally pertinent in terms of the objective" (Kahn \& Cannel, 1962, p. 52 mentioned by Minayo, 1994, p. 108).

Through the phrase: "Tell me how the positive result was disclosed to you here at the CTC" each interview was initiated for the conversation to center around counseling, the moment in which the result of the anti-HIV reagent serological test was disclosed.

Based on this indication, some free space was created for the subject to build a narrative in his own way. The interviewer introduced questions, whenever necessary, to obtain the information regarding the objective of the research. These questions followed topics that were broached, but without a previously established script. The client could speak freely about the issue in focus, as in the procedure called personal testimony, topical life story or oral history (Minayo, 1994; Queiroz, 1991). The client was invited to speak about this period of time experienced, which remitted to the event that had taken place at that moment of his life and that was the object of investigation: the disclosure of the diagnosis of infection by HIV.

The use of the interview was aimed at bringing to the surface the plot of this moment full of meanings, difficult to access and share, and that has subjective interferences in the narrative of the interviewee, resulting from his memory, the experience of the situation and the interviewer's approach. Each subject organized the sequence and the content of the narrative as he preferred, and could come and go, stop, have repetitions, besides leaving some gaps that arose due to flaws in memory, motivation and/or perception. These aspects were important in revealing the feelings or mental representations of each of the subjects upon experiencing the disclosure of their diagnosis of HIV infection, and on how they perceived the counseling they participated in.

The researcher's role was also determinant in the continuity (or not) of issues relating to the context of the disclosure of diagnosis, as, depending on the unique condition of each of the interviewees, the path tread by the narratives could become very diverse and move away from the study-s core focus of interest. The researcher's listening attitude and availability at the moment ensuing counseling was favorable to the appearance of meaningful psychological content among clients. The atmosphere of interviews was always relaxed, easygoing, allowing the interviewees to freely express themselves, and the work only ended when the person being interviewed said there was no further information to add. The duration of the interviews varied from 45 minutes to one hour and 15 minutes.

The interviews were taped and transcribed so as to ". . . maintain as much as possible the expressions used by the informants and their way of linking the facts ..." (Queiroz, 1991, p. 60-61).

At the end of the first meeting with the volunteer, a second interview was always proposed, freely allowing the person to choose to participate or not. Among the volunteers, eight came to the second interview, while another six did not. There were eight people that did not appear for the first interview, with two women being part of this group. These people set up appointments, but did not appear or cancelled before.

The inclusion criteria for the research were: (a) being 18 or over; (b) having a reagent result in the Immuno-enzymatic Assay serological test (Elisa) and the confirmatory exam Western Blot or Immunoblot; (c) having participated in the disclosure process of the HIV diagnosis at the CTC's studied; and (d) having voluntarily signed the Free and Informed Term of Consent.

The number of subjects in the study was not defined a priori. A maximum number of volunteers was established, because of criteria such as: the difficulty of attracting volunteers and the 
consequent demand and extension in the collection time, that was four-fold compared to what had been foreseen initially, the repetition of content at the same center, the quality of the data obtained based on the interviews and the qualitative nature of this survey. The number of people included was the same at both CTCs.

Twenty interviews were performed with 14 subjects. The interval between the first counseling and the interview varied as a function of the time each client took to pick up the results. The interval between the first and the second interview of the survey oscillated between one and two weeks, according to the convenience of the subject in undergoing the interview. It took one year to collect the data (between the dates of the first and the last interview).

To be able to analyze the interviews, each one was considered as a unit of meaning within the corpus, defined as a set of documents to be submitted to analytic procedures (Bardin, 1977/1995).

The analysis was preceded by a careful examination of each interview, considering it as a whole, seeking to understand its logic, ambiguous, contradictory or unconscious aspects, so as to capture in each story the disclosure of the diagnosis of HIV infection in the people interviewed.

To have systematic and organized data, the content analysis technique was used, making cuts in the narrations, guided by analytical categories built based on the research objectives. These objectives are based on essential aspects that have to be present, by definition, in serological counseling, according to the standards of the National STD/Aids Program. This is how the corpus was constituted.

What was used as a guide in reading the interviews and organization of results was the fact that the centers followed the same protocol and the same guidelines for counseling.

The use of concepts extracted from Winnicott's theory, based on which the present survey was structured, served as an interpretation tool and analysis matrix, whose construction arises from the interaction between the initial work hypothesis and the corpus (Blanchet,
1992), constantly seen, reviewed and articulated. This constant interaction made it possible to operate them as concepts used outside of their original field.

The research project was submitted and approved by the Ethics Committees in Research at the School of Health from the University of São Paulo and the Municipal Secretary of Health of São Paulo (CAAE 074/2003).

\section{Results and Discussion}

\section{Research Subjects}

All of the interviewees were of the male gender, with ages varying between 21 and 65 years of age. The predominant schooling was between 8 to 11 years of studies completed, followed by 12 or more years of study. Only one interviewee referred to having completed between 1 to 3 years. The category of exposure to the HIV infection was sexual, being that the majority of the interviewees had a homosexual orientation. Two of the interviewees were identified as having a heterosexual orientation. Most of the interviewees had a steady partner at the time of the survey, but only three had had one or no partner during the last year. The rest had had more than two partners in the last year, with one sex professional having had over one hundred partners.

\section{Analysis and Interpretation of the Content}

The drafting of results was based on the construction of categories, relating to the survey objectives. The empirical material will be presented, if deemed to be relevant, to illustrate the analysis and to be used as an element to understand the result disclosure processes experienced.

The first category summarized the research, in terms of the client's listening and his centrality in the result disclosure process for the HIV diagnosis.

An analysis of narrations showed that clients are divided into two groups, that very generally correspond to the affirmative or negative answers to the issue analyzed. Thus, two of them (Paulo and Omar) explicitly manifested their negative opinion regarding the issue involved: they did 
not feel at the center of communication, nor did they feel heard in terms of their feelings and concerns arising from the disclosure of their reagent result. The remaining twelve considered that this objective was attained in the disclosure of their reagent result, being heard and acknowledged as being at the center of the conversation. They are: Sílvio, Milton, Nei, Luís, Juvenal, Evandro, Arnaldo, Mário, Pedro, Cássio, Bruno and Jonas, all of which are fictitious names.

Although they deemed they had had satisfactory counseling, what can be noted in their narratives is that not all were able to speak to the counselors about issues such as shyness, as counselors were all women, or because they did not feel they had the right to take the time of these professionals:

It is, I believe that the man with a woman, when a shy man comes about, he is going to be ashamed of speaking to the woman. I think that, with a man, he will not be as ashamed, it's going to be a man with a man, right? Then, maybe sometimes, he will ask more things, because he is a man. Now with a woman, the man, he can feel ashamed with the woman. As there are men that are, right? . . after some time then I can come in and ask more things that I want to ask. . . The first time you come ... you can't even find the question to ask. Then he asks some things, out of ten he's going to ask about two. Do you understand? . . . it is because we think the time is very short and that it will take too long if we ask too many questions. Then all of this remains in our head, right: "no, if I ask too many questions I will be cumbersome for them". (Sílvio)

They identified with the concerns geared to "from now onwards", the manifestations of the disease and to something that the clients did not yet understand at that moment. Part of those interviewed did not readily believe the result and needed some time to accept the idea of being infected with HIV, making use of denial and rationalizing mechanisms. Both of these defense mechanisms were only accessed by the interviewees when there was welcoming and support on the part of counselors.
Another type of denial relates to the difficulty of accepting exposure to a risky sexual situation as the route to infection. One of the interviewees insisted he had contracted the virus by sharing a sharp cutting object for personal use with a friend (Evandro). Based on the data he provided, this would not have been possible, and what was underlying the denial was his difficulty of admitting his homosexual orientation, as was explored in counseling.

Among the feelings reported, the fear of depending on others was frequent, of depending on those they lived with and of being abandoned by them (Luís and Paulo).

Even though the conversation space had been established, a transfer to another center was one of the reasons that interrupted the discussion of issues with clients of counseling services: "I felt like speaking to somebody about what was happening, but there was not enough time for that, because I was already going to the SAE [Center for Specialized Attention in STD/Aids]" (Milton).

. . . she spoke about this place that she recommended, that there would be a psychologist there. Therefore . . . if I want to talk to a psychologist, they have some there . . . the center here, it's basic services and that is all. (Luís)

The open space for conversation in counseling and the care at disclosing the reagent result allowed subjects to speak about their issues, as the ones described below.

In the case of Evandro, his denial of his condition as a carrier of an incurable disease became evident, as he considered the HIV infection as being liable of cure. This client also found himself undergoing a process that denied his own homosexuality. But in the counseling process he felt as the center of the conversation, having his space preserved and feeling respected in his beliefs.

Differently from Evandro, Juvenal accepted his HIV positive status as a fact that would not be denied. And, in a certain way, he did this rather complacently, despite not expecting to have been infected with HIV, and not always having had safe sex. 
Pedro took full responsibility for his lack of protection against HIV in his last amorous experience. He was still very much under the impact of the loss of his companion. A large part of the interview was devoted to speaking about this.

The story told by Jonas pointed out that, despite the space opened up and the intersubjective contact, what appeared was a very tenuous line between care and reprimand. He explained that formerly he had had about fifteen non reagent tests, he felt the counselor became frustrated due to his lack of use of prevention, which caused the HIV infection. Luckily, in his case, it seems to have been possible to clarify this through dialogue. After "everything sinked in" he was able to take responsibility for his lack of prevention (or hesitation, as he calls it), because there was time for that and he was able to explain how he was feeling:

It was pretty stringent like that. I think she messed up, not that she really dropped the ball, but she was very stringent, like this "well, you are condemned, but at the same time, you still have a chance", you know. I thought that was very harsh, that's it. But it was that moment of tension, which in a certain way opened up my mind to say "hey, you are wrong, you have to admit you were wrong and now, as of this moment, you have to do things differently". . . . I exposed myself. . . I said what I was feeling at that moment, without fear. (Jonas)

Caution when disclosing the result was one of the characteristics signaled out by the clients, as well as the need to create a bond of trust. One of the interviewees who was already familiar with the center and with the counselor who disclosed the diagnosis of HIV to him told us that, days after having received the test result, he came spontaneously to the CTC to once again be able to talk to that counselor. That means he confirmed he had had the space to talk to her about what he was feeling, based on the trust that counseling had mediated. He felt supported and welcomed by her, especially for having been seen by her without having set up an appointment.

I felt a great deal of trust in her [in the counselor] ... I had to come here only tomorrow.
I said: "no, I'm going today, because I want to talk to [counselor's name]. I want to see what else she had to say to me". ... Because on that day I did not want to talk very much, I had no way of telling her. ... Nothing had been set up. I simply asked her if I could talk to her. ... She received me so we could talk. She's being great you know? ... I have nobody to share this with, get it? And there I am talking to her. . . . My first negative exam was delivered by her, you know? The second sample, no. And this one turned out positive, it was also her.... She gave me the phone number for this center as well . . For anything I might need. (Bruno)

Omar and Paulo did not feel they had been put at the center of the communication for the result disclosure. For that reason, they were unable to speak to their respective counselors about their feelings and concerns, conveying the most negative versions of what was processed at the moment of disclosing the result.

In the survey interview, one of the interviewees tried to create a fictitious dialogue with the counselor, in which he imagined how a client could feel more welcome, but that did not happen with him. The intersubjective relationship experienced in the counseling activity was impersonal:

... as I believe there was no preparation, to give the news, because she was concerned with filling in the administrative documents that were part of the process, then any question that was posed regarding my feelings was no longer valid there. In truth, it has no effect whatsoever. Get it? Because no matter how hard you try to comfort the person, it won't have any impact, right? ... I'm the one who is going to convey that information to that person? Great. Then I'm going to put myself in her shoes. Not make this such a straightforward thing or then, yes. ... One more! Got it? Like that. . . An ordinary thing. Because you do the same thing every day, so you end up losing you sensibility. That is what I felt. (Omar)

This perception hampered the second intersubjective experience that took place between 
this client and the counselor who gave him the result of the confirmatory test. He refused the help relationship offered, despite the perception that it was all about a counselor with her listening more centered on the client. His story and his personal issues, therefore, were never approached.

The second time I went . . the person who talked to me seemed to have more sensibility, right? ... so I felt a little more welcome, sheltered, right? But I already knew the result. . . There was a gap there, you know? You know when there is this vacuum? And I was thoughtful. [He speaks as if he were the counselor] "All well Omar? . . What are you feeling?" . . . But, I couldn't do it, you know? It's overstepping, bursting out with my emotions. (Omar)

The other interviewee who had the negative feeling, of "automatic attention", was Paulo. In his first post-test counseling, according to him, there was no preparation to disclose the reagent result, nor any space to talk about his feelings and emotions arising from this event:

My feelings? Of what? Of the news? . . . Very automatic! . . Imagine that you have a card for a 24 hour bank, your card goes in and out. . . It was all very quick! . . No . . . There was no space. This space was subsequently questioned, when I was standing up, but then no longer, if after that news there was no initial preparation, why would I want that afterwards? (Paulo)

Clients expected to obtain some relief for the suffering caused by the disclosure of their diagnosis, and were able to obtain it when the counseling processes experienced had been centered on themselves as subjects of their own history of infection.

In the interviewees reports, what was identified was that they had nobody to talk to, sometimes, nobody to live with, and a feeling of anxiety for being alone.

The interviewees also mentioned the need for the counselor to respect each person's rights, of being able to choose between having the result disclosed with great caution, postponing it, after the usual and habitual procedures at the center; or, quite the contrary, of having the result be given immediately, "without beating around the bush", as soon as they entered the counseling space.

According to Winnicott (1967/1975a, 1951/ $1978 \mathrm{~b}$ ), the notion of space is closely tied to that of time, when it comes to the first contacts with reality.

The process begins with the infant's first experiences in adaptation, when the mother presents the child objects, on the right dose, so as to give the child an adaptive supply. Thus,

. . . the mother is able to operate like an agent of adaptation [who] presents the world in such a way that the child will begin with a supply of the experience of omnipotence [underlined by author], that constitutes the appropriate foundation, so that subsequently the child can come into contact with the principle of reality. (Winnicott, 1968/1999a, p. 13)

While the infant is not apt to tolerate frustrations and conflicts with reality, the mother waits, postponing this until it becomes bearable for the child. Implicit in this is the author's notion of an "enabling environment".

Making that leap to the situation of disclosure of the diagnosis for the HIV infection, what clients have shown is that the delicate nature of the situation requires the presence of a counselor, making it possible to wait, in so far as possible, for each one, that is, the latter would have to function as a sufficiently good mother, presenting the objects of reality as soon as she perceives the client can bear the frustrations. The counselor's presence is also absence, so that the client can begin to set him/herself up as a separate being, gradually and also more independent in relation to his/her own condition as an HIV carrier.

Regarding this aspect, what was also observed is that the result of the second sample (confirmatory test) allowed clients to better develop the process to elaborate or create their own diagnosis, like a sort of adaptive function. Part of them attempted to have the hope that the result of the second sample (communicated at a second meeting) would be non-reagent, but confronted with this confirmation of a reagent serology, being able to have that shared space in which they could be heard helped them to bet- 
ter deal with the anguish, and to better prepare their treatment plans. The two factors (time of preparation and listening time) seemed to have had a favorable effect for a better psychological condition, to return to the center in search of the confirmation of the result.

Filgueiras and Deslandes (1999) observed and analyzed counseling at various Brazilian centers, and obtained similar findings to those of the present survey, with regards to the welcoming attitude and the listening attitude on the part of counselors. This was one of the counseling characteristics that were oftentimes hampered at centers researched by these authors.

The approach on information referring to STD/Aids prevention, adherence to Antiretroviral Therapy (ARVT), and self care was observed at all of the counseling situations, heeding the recommendations of the STD/Aids prevention programs. Such information is aimed at stimulating the individual to care for his/her health, with the goal of increasing survival.

Most of the questions posed by clients during counseling relate to the effects caused by HIV in the organism, and the specificity of tests and treatments that would be needed. Clients were oriented to clarify their doubts at another reference center, with a physician or another professional, depending on the case, or the counselor herself clarified these doubts during counseling.

Despite this guidance, nevertheless, the spaces of interlocution and negotiation in the counseling process were hampered by personal issues that were not explained at the time of result disclosure, but were later reported in the interviews, and that made it difficult to seek clarifications. In a certain way, these barriers keep these people in their state of individual vulnerability, not allowing them to deal with the infection, with the disease and with the use of prevention practices.

Souza et al. (2008) in their surveys also identified different positioning of the interviewees with respect to the need or outlook for change of their status of vulnerability, and also with regards to decision making and the construction of a prevention alternative.

In the present survey, an interviewee suggested that the information be provided in wri- ting, through an educational leaflet. He deemed that if the person was anguished, he would pay no attention to the information which later would become essential for health care.

This suggestion went along the same lines of what was standardized in 2001 for testing and counseling at the Center for Disease Control (CDC) in Atlanta, USA (Galant, 2004). Based on these standards a hand out was drafted containing information on how to diminish the risk of HIV infection, and the resources available for health attention, respecting culture, language, gender, sexual orientation, age and educational levels.

Information on scientific progress leading to a possible cure was also requested by clients during the research interview, suggesting that in the process of disclosing the diagnosis, questions referring to these had not been posed.

". . . as time goes by, will there be a cure?

Do you believe there is the possibility of having a cure, for Aids?" (Nei).

Despite the doubts that remained pending, interviewees stated they had gained an understanding regarding the need to take care of themselves, and also of not transmitting the virus, being convinced with regards to this, without losing hope that one day a cure could come to exist for Aids.

During the result disclosure, in general, what was discussed was content referring to the viral load, infection due to opportunistic diseases and other diseases, besides treatment, sparking in the individuals the interest in life. Content on unprotected sexual practices was also part of the counseling, with reinforcement on the need to avoid risk involving these practices.

"I now think of living, not weeping over spilt milk, continuing on with my life, taking care of myself and avoiding transmitting the virus" (Luis).

Clients received further guidance about the need to visit another center, to evaluate their viral load and for the moment to begin treatment.

... If I have to have that load, I'm going to have to bear it; I am not going to share it with anybody, you know?. . I want to see the result of this, how it is first of all, to get to the medication and much more. Because 
now I will take those exams on the week that I am going to see the doctor, they have already transferred me there because there will be more there, got it, a greater progress. (Luís)

According to these findings, the clarified and explanatory nature of the reasons for referring patients may favor that passage from the CTC to the SAE. This referral to the reference center closest to their site or residence depended on the agreement of clients, as there was a demonstration of fear due to the possibility that there they might find people from their neighborhood, or acquaintances that could discover the diagnosis of an HIV infection and discriminate them:

It is an open place, there are a lot of people looking at us. . . You are out in the public; everybody will know, your neighborhood and we'll go back to the issue I mentioned. . . . Of discrimination. Because not everybody will sit next to a person with Aids on the bus and not everybody will take a sip of water or of beer from the same glass. . . Not everybody will share the same clothes. . . . Here, when you arrive, they call you into a room and talk to you . . you are protected. And there ... there is no protection of your identity; you are exposed to everybody. (Arnaldo)

Thus, privacy and confidentiality proved to be essential in the counseling situation, as this is a guaranteed right and because of the clients' experiences, as of the moment of disclosure of the result, and their difficulties in making their condition as HIV positive public. This is an indicator for centers to devote themselves more to working geared to the feelings linked to the client's identity construction, which is altered by the result of the test. This alteration seems to be directly tied to the threat of living stigmatizing situations because of their fear that their infection by HIV may become known to other people. These subjects seem to be living (and suffering) this stigmatization internally. And they were fearful this would get out, that is, that others would stigmatize them when they discovered their positive serology.

At the moment of the interview for the research, Evandro and Paulo had already come in contact with the respective assistance centers in STD/Aids, those closest to their homes. Evandro went through a counseling team and had set up a visit with the physician specializing in infections. Notwithstanding this, Paulo received the information that he would have to get a number to be serviced on the first day, which raised some concerns regarding the welcome at this new unit, and the possibility of having to face a delay in setting up this visit.

Integration between the centers, and the knowledge of their attention routine proved to be necessary to minimize this type of concern felt by the client, and to enhance the quality of information during counseling. With this, the client was able to feel more secure upon leaving the CTC, favoring adherence to the treatment recommended in his case.

Clients felt inconvenienced with the questions posed in counseling, associated to the need for prevention and the offer of condoms. These procedures did not always respect the singularity and the suffering of the moment, as they were not always managed in a delicate way:

... I was asked if I had any doubts [about prevention] after the questionnaire. How many partners I had had in the last ten years. How many condoms I wanted to get, I found that to be ex-tre-me-ly harsh and cold [highlights the syllables]. . . Not that the professional has to, will not become emotionally involved with the patient, but the one that is there has to be very well trained. They studied for that! Whoever is there is finished, is destroyed, torn to pieces. .. I am not going to remember the last ten years . . . Of how many partners I had, of how many steady partners . . How many condoms I want to get . . I I even said to the person: "ah, ten condoms" and she said: "only that?" I said: "only". . . After a result like that one, at that time. . . it makes no difference if I take twenty condoms or none at all. . . . All I want to know is how to deal with this first. . . Then, for me it makes no difference to get some condoms downstairs. I have no sexual life at the moment. Did she by any chance acknowledge that? It's null, zeroed out! (Paulo) 
Confronted with this perception, the effect on the client could have caused damage, in the sense of (not) activating that person's internal resources to face up to the diagnosis and to the desire to care for his health. However, Paulo had a good ability to defend himself and, furthermore, had the opportunity of a second counseling with another professional. This counselor made it possible to set up a new relationship of help and mutuality. It can also be said that this counselor made it possible to create the third area highlighted by Winnicott (1967/1975a) as

... a field of experience [underlined by author] in the potential space that exists between the individual and the environment, that which, from the beginning, unites as well as separates the infant from the mother, when the latter's love, demonstrated and made manifest as human trustworthiness, in truth offers the infant a feeling of trust in the environmental factor. ... The potential space between the infant and the mother, between the child and the family, between the individual and society or the world, depends on the experience that leads to this trust. It can be seen as sacred for the individual, because it is there that he experiences creative living. (p. 142)

Extending this to the situation of an analysis, for the author, it is important that the analyst comes to realize this place of continuity-contiguity, that is found where the transitional phenomenon originate and is located between both (Winnicott, 1967/1975a).

The other interviewees positioned themselves differently from Paulo, when it came to the referral, not presenting any further doubts on prevention and on treatment, as it was possible to clarify these within the counseling space. This is the case of Bruno, who was able to recall the situation when he became infected, and was also able to speak about his status as a sex worker, even having pointed out that he perceived that people suffered prejudice because of this. This client was fully aware of the risk he ran in his sexual practices as a sex worker, demonstrating his negotiation power and attention to protection rules, but in the affective relationship moved far away from that internal knowledge, leaving it "on the outside", not adopting it.

As Omar's disclosure experience had been a negative one, he internally was not available to assimilate any further information on prevention. In his opinion, there was an excess of information and a lack of intersubjective space to be able to convey such information.

... That is the result! If I hadn't been prepared to receive that information, the second time of the confirmation, I would not have taken part in that interview [of the resear$\mathrm{ch}$, I would not have done anything. Why? It is the feeling and everything else. It's too much paperwork. You end up like this: "my God!" . . . And then I continue on the street there, crazy, "pretend that I have nothing". And ... Dead end! And I'm going to lead my normal life. Is that the intention? It isn't the intention, is it? (Omar)

The tone of his speech was one of indignation and protest against the way in which he was treated in the counseling situation for the first test. This experience could have hampered his participation in the survey, which interested him and to which he wanted to contribute. Nevertheless, Omar shows he hasn't closed down completely.

There exists the need to strengthen the tie between prevention and assistance, and that can only be initiated through the counseling process. The degree of the tie and of understanding is the first step towards this.

Three of the clients participated in another survey that guaranteed treatment at a center of excellence, but the first referral made by the counselor was at a reference center closer to their place of residence, which is where Jonas was directed initially.

. . honestly, I found the place to be rather negative . . the service there was totally precarious. I saw that as a citizen that was not going to satisfy me, you know. . . Not simply because the person has a positive status should they be in that treatment. I believe things could be a little better. . I think they could be a little more humane. And I did not feel well there. (Jonas) 
Despite the negative aspects that were pointed out, and the differences between the counseling researched, all of the narratives presented show that the aspects involved in this category of analysis were contemplated, to a greater or lesser degree. The difficulties seem to have resulted from that hampered link between the counselor and the client, and from a certain malaise provoked by the change in the institution offering the assistance. Although they recognize the complexity required in the sequence of their treatment, that separation of one site of attention that is known and is welcoming to another site generated anxiety for part of the interviewees.

Practically all of the interviewees came out of the counseling situation convinced that they would continue to practice safe sex, and with the desire to care for their health, be it by leading a life with healthy habits, or adhering to the treatment that would be recommended in each case. When confronted with such facts, it can be assumed that the objective analyzed of reinforcing prevention practices, and of stimulating treatment and self-care were attained in a satisfactory way in the counseling researched.

There are several recommendations made by the National Program on STD/Aids that refer to the content that should be approached, and which is not always possible to deal when communicating the reagent result. Therefore, the analysis will have as its focus the aspects that were prioritized in the disclosure processes for the diagnosis of HIV infection described in the present article.

Aspects such as filling in the epidemiological questionnaire, overcoming the difficulties of sharing the news with others, and the offer of visit schedules were the ones that most stood out in the counseling reported.

The first, Filling the Epidemiological Questionnaire, refers to a procedure instituted in CTC routine, that all of the interviewees made reference to. It refers to standard questions with the aim of raising epidemiological data, which is important to understand the profile of the epidemic, making it possible to schedule actions destined to the fight against and prevention of Aids.

About three of the interviewees considered it was uncomfortable to respond to these ques- tions, as they had to search their own memories. This discomfort was associated with the fact that they had to stir up their memory for sexual practices (or those of another nature) in that quest to attempt to characterize risky situations of exposure to HIV infection. This questioning caused discomfort among these interviewees, as it has already been mentioned.

The issue of having to count the number of condoms in sexual relationships was also approached, not only referring to past use, but also to the offer of a certain amount of this product for use in future relationships. This last aspect seemed out of time and place, due to the complete stop or interruption in projects and desires at that moment, as was the case with Pedro (still under the impact of the loss of his partner due to Aids) and Paulo ("zeroed out" in his sexual activity because of the discovery he had a positive status).

Frequently the dynamics set forth in counseling, and the way the questions were approached caused the impression in these subjects that the task of filling in the questionnaire was more important than recognizing these individuals as persons. Counselors in these cases were functioning as an intrusive mother, with an invasive presence which does not offer the other the permission to speak (Winnicott, 1954/1978a).

Albeit recognizing the limitations in the role played by the professional, it is important to identify the possibility of sustaining and welcoming the anxiety that emerges in this situation. This skill is fundamental and cannot be lacking in a counselor, not to resolve the problem alone, but instead to carry out the role of a depositary of the anxiety the other one brings. Therefore, it is about constituting a holding, and an environment of provisions involving both, not only the one undergoing counseling, but the counselor as well, forming the mutuality. With this, suffering can be shared and supported, not allowing that an aspect such as the amount of condoms to be offered occupy a privileged position, nor cause abandonment and revolt as it was mentioned.

In that same direction, another client pointed to the way the questions were posed, causing an increase in his expectation and anxiety regarding the result, and of the distance between the counselor and himself. He felt that the formal 
and bureaucratic aspects of the institution had more value than the human being-client, that the subjectivity did not seem to be guaranteed:

She continued writing down some data, and then you begin to feel somewhat apprehensive, right? ... "Speak out so you don't have to beat around the bush". Although I think that ... for you to convey news like that, ... I think you have to do without the administrative part a bit, because you are dealing with a person. After you have given the news, well then you can go back to working on the paperwork. Do you understand? You know, that somewhat mechanical thing. Somewhat no, totally mechanical, right? (Omar)

Notwithstanding this, not all of the interviewees felt uncomfortable with having to fill in the questionnaire, even considering how difficult it was to recall things of the past " . . that you are no longer doing [and that] you wish to forget ...", as in the case of Evandro.

These reports show that there is no single way of approaching this procedure, as people are different one from the other. What does seem to matter is the setting created, which begins from the moment in which the client calls in to set up an appointment for counseling.

For Winnicott (1968/1994a), referring to the therapeutic visit:

The basis of this specialized work is the idea that a patient ... will bring to the first interview a certain ability to believe [underlined by the author] that he will receive relief, and trust the person offering this. What is required from the latter is a strictly professional setting, in which the patient will feel free to explore the exceptional opportunity that this visit offers to communicate. (p. 230)

Based on what has been presented, the therapeutic visit is a device whose practice produces therapeutic effects in clients that take part in it. Because of the findings of this survey, it is deemed that this conception could be used to produce referrals to centers of attention and assistance in collective health, mainly in the context of serological counseling. Based on the client's demand for analysis, the analyst will conduct or lead the analytical work. As there are demands for psychotherapy, whose work is more geared to confronting a symptom, Winnicott developed the modality of the therapeutic visit. In these visits, the focus referred to the possibilities of working, regarding time and the type of problem brought forward. Although there is a fundamental difference between this modality and counseling for the disclosure of the reagent result, it is considered that an approximation between these two approaches could be promising, not only for the client, but for the counselor as well.

The offer of a different counseling schedule made by the counselor was another aspect that was raised by the interviewees. This possibility of going back at other time(s) to chat, if they needed to, was offered in both centers. Nevertheless, a minority took advantage of this offer. Oftentimes the intention to return was obliterated by the indication to continue with the treatment at another center, to be able to begin treatment, as illustrated in the report:

I even said: "I'll go there, I have been referred there, but can I come visit you every once in a while?" [the counselor] said: "yes, you can, no problem at all. Whenever you want to come, all you have to do is set up an appointment" ... (Pedro)

That consent given by the counselor expresses the possibility of new encounters, but there is an ambiguity, as the client has been put on the path of another health center.

These issues point to the complexity and the amount of information that has to be conveyed at the counseling meeting. Precisely for that reason, at each counseling, the priority should be the more pertinent issues, based on the client's needs at that moment, respecting his uniqueness.

These considerations point to the fact that additional schedules may be of the utmost importance to placate anxiety in terms of the information that has to be conveyed, not only for the counselor, but also for the client. Additionally, it is possible to reflect upon ways to put in place that offer of additional schedules. The client seems not to become engaged, as he is halfway between the CTC and the other site of attention. $\mathrm{He}$ is in transit, but has not reached his destination so far, having already left his place of origin. 
Overcoming difficulties when sharing the news with others was an issue approached by the counselors, and it became a priority in the counseling experienced by interviewees.

The topic appears in a diversified way for each client interviewed. For Sílvio, Evandro, Cássio and Milton, this was an essential issue and one of concern. Not only because of the fact of the disclosure per se, but also because of the need to propose to partners that they carry out their own anti-HIV test.

For another person (Mário), the difficulty in breaching confidentiality referred to his family. Mario's mother was completely unaware of the positive serology of his own brother, for example, who had been diagnosed previously.

Others (Paulo, Pedro and Milton) reflected on who would be the most indicated person in the family to give the news to, as they had no proximity with all of their family members, and did not trust they would understand anything about the disease.

Luís and Juvenal, who had no family in São Paulo, thought about who would be the people in their circle that could sympathize with them.

Finally, Nei and Luis were concerned with disclosing the news at work. The fear of prejudice that exists and the discrimination that could arise was their predominant feeling, and the factor that impeded communication of their serological status to third parties.

The space given to talk about prejudice, and the difficulties involved in revealing their serological condition varied, depending on the counselor-client duet, and the difficulties in listening and creating that tie, as pointed out formerly. What also varied considerably was the situation of the interviewees' affective relationships, which determined the multiplicity of approaches and diversity in the questions that were raised.

In the case of Silvio, counseling was very much centered on how (and who) to disclose the diagnosis to his partners, due to the fact he had a stable relationship with two women, simultaneously. He mentioned that the help of the counselors was fundamental in dealing with the problem. He brought both women to the center, one at a time, to take the test:
... I brought the first one, whom I am with now, and who is the mother of my three children. I brought her. . . The other one knows nothing so far. She doesn't know, I was unable to talk to her, so much so that I spoke with the girls here [the counselors], if it wouldn't be easier for them to talk to her .. . because she is very nervous, you know? (Silvio)

And that was what was done by the counselors at the CTC. This interviewee found it difficult to tell them that he had had other encounters outside of the conjugal relationship he had with both. It was through one of these that he got HIV. To tell he had the virus meant to disclose he had had extra-conjugal relations. The disclosure of the reagent result makes it possible for unique issues such as this one to be worked on by the subjects of counseling. The revelation of infidelity goes on to being the greatest problem to be faced when sharing this news. The presence of women at the CTC, to communicate to them the positive status of their companion, was something unheard of for the CTC. Despite this, he was being welcomed and sheltered by the team at the center to deal with his family problems arising from his HIV infection. The answers are not always readily available, and they are not always ready. Sometimes it is necessary to build and rebuild the ways of resolving the problems that appear.

To tell this to his family, one of the subjects was the one that became more anxious and considered it was necessary to approach this theme in the counseling process:

... I think not, it should be approached because... who is the first person I'm going to tell that to? "Look people, I'm an HIV carrier", got it? But, like that, I don't want this to become a big thing. . . I don't want to involve the family, but there is that somebody that I want to mention this to, but how am I going to mention this to that person? . . . This has to be elaborated, worked on, I believe. When I leave here, I will be leaving alone. And I know I will continue on alone. But sometimes the conversations can even help a bit. (Paulo) 
But even though he considered that it would be important to speak about how to disclose his positive status to others, this interviewee did not have that chance to do so in his counseling:

Black, poor, japanese, poor people or not, ignorant people or not, people with higher education or not: whoever is here, is alone . . . "who can I trust in?" . . that is why I believe there should be those spaces... I am not questioning you either, if it hasn't been given. I also did not ask, but this is something that should be analyzed. (Paulo)

That aspect of telling at work gained considerable importance for those interviewees who felt that their jobs may be threatened by their positive status in the HIV tests. Half of the clients were working outside of the formal market, and this did not pose an issue for them, as was the case of Sílvio, Milton, Evandro, Cássio, Pedro, Mário, Arnaldo and Jonas. Others in a certain way felt secure in terms of their respective jobs, as was the case with Paulo, Omar, Bruno and Juvenal. Nevertheless, for Nei and Luís, telling the result in their workplace was a huge issue for several reasons:

One of them (Nei) thought it would be complicated to share this at work, because he had been working there for only three months and because one of his colleagues had suffered prejudice and was ostracized for being an HIV carrier. The possibility of being discriminated and being treated in a stigmatizing way $s$ in that environment concerned him, but he believed that at least his immediate boss should know.

The other interviewee had already suffered a great deal of prejudice and discrimination for being homosexual. Frequently, he had to confront people at the workplace to gain respect. He additionally faced labor problems linked to labor accidents that had not been duly resolved by social security so far. In his counseling, the possibility of seeking out the social assistance at his reference center was mentioned, to receive guidance on his rights as a carrier of the disease. This was important, because it offered him a possible route to resolve this conflict. Notwithstanding this, he had several concerns regarding his job:
.. . a man who is homosexual, he is already targeted, he is criticized and with the disease, my fear is in the company because I have already been severely criticized . . I, I'm not going to tell, in the company, and even if I do ... that is going to add to the complications. "Besides being gay, he has Aids". ... This is what I believe in my mind, that way, you know? ... And now with news like this one, if they start speaking about you it's. ... Then I think I will tell at home, after this result with the social assistant, I will see. ... If I continue to make the same salary, I prefer to stay at home and work like an informal salesman on the streets. (Luis)

Analyzing the reports by using Winnicott's theory (1971/1975b, 1965/1994b, 1986/2001), it can be considered that when the setting is set up in such a way that it sustains and supports the subject's anxiety during counseling, it makes it possible for them to act naturally and, beyond that, to bring to the surface the story and each person's psychic constitution. As it is still feasible for the individuals to use their own mechanisms (denial, projection, rationalization and others) already developed as part of the resources of the ego. These mechanisms can be reached, enabling them to defend themselves from the horror that this situation sometimes evokes, even if they consider that this is a consequence of the practices they have adopted in their life.

In Winnicottian terms, this situation can be considered to be a break in the continuity of existence, considering that in a certain way it interferes in that path towards the individual's independence. The continuity of Being will be made possible by the creation of an enabling environment, that will permit the reconstruction of damaged aspects.

Thus, for the setting to come about in this "supportive" way, it is necessary that specific functions in the environment enable the resources of the psyche to come into action. The subject possesses them, but needs the chance to use them in that process of preparing feelings and resolving conflicts that appear at that moment. This was put into action in the counseling researched, in which the presence of the counselor 
allowed the clients to "use her". This is an expression from Winnicott, that means: providing that adaptive supply of provisions for the individual to have the time to recover and use his own.

The standard interview (compiling of epidemiological data), which had been unbearable for part of the interviewees, for others was part of the holding. According to Winnicottian analysis, what can be suggested as an explanation is that the management of the situation made it possible and created that condition of holding. The holding enabled these clients to gradually come into contact with the reality of the news. The defense mechanisms pointed out worked for a period of time, only for the necessary time. If used excessively, these mechanisms could create falsehood, a sort of a mask to avoid suffering, due to the result that was so feared (but known already). They stopped acting out when each client who had undergone the support experience was able to tolerate reality with the help of the counselor, and what she represented for them.

\section{Conclusion}

The majority of interviewees felt there was availability on the part of the counselors at the moment of disclosing the reagent serology, based on which they were able to experience a relationship of closeness, proximity, sharing and care. In this context, they were able to speak about their concerns and be heard, receiving the necessary support and giving meaning and sense to their experiences of having been infected by the Human Immunodeficiency Virus. This possibility enabled them to understand and transform the issues or questions they had brought with them, and to put into play their emotions and the concerns they felt at that moment. Therefore, in these cases, as the time and the space to be heard was made available to them, their defenses weakened and reality presented itself ever more, enabling them to reveal their true feelings, particularly those relating to the loss of integrity of their immunologic system.

As a counterpart, for two of the interviewees, it was not possible to fully develop that experience, of listening to their feelings and concerns. In the counseling process there was no opportunity to truly hear them and thus activate their psychological resources, enabling them to sustain their affective manifestations when faced with the disclosure of the result of the anti-HIV reagent. Therefore, the counselor did not always operate like a sufficiently good Winnicottian mother, providing sufficient time and space for a shared experience of mutuality, support and help.

In summary, in most of the counseling researched, the creation of the adequate and welcoming space took place, providing these clients with that adaptive supply, whilst not the others. This means that the counseling practiced at the centers researched worked well for some, when carried out in the full extent of the listening, with this allowing for the psychological resources of the subjects to come into play, and effectively giving them the necessary emotional support at that moment. However, it was not favorable for others. When that came up it was simply something normative, the standard, abolishing the unique listening attitude and sharing that makes it possible to have that transitional experience, in the counseling process, to disclose the diagnosis of infection by HIV. That is, in these cases it was not possible for the subjects involved to receive the necessary emotional support to sustain their suffering, when confronted with the disclosure of their diagnosis of infection by HIV.

It can be concluded that in counseling, when the professionals create a space so that each unique subject can present his own story and demands, they can undergo that positive listening process and offer the necessary emotional support at that moment, and empathy is the necessary condition to attain that. In the version stated by the subjects interviewed, counselors were only able to come closer to their feelings and perceptions regarding the result of the test, to offer support, when they had the ability to put themselves in the position of the interviewees and interact with them, taking into account their viewpoints in terms of the results. Because of this, serological counseling can prove to be a technique for help, that will aid clients and make it possible for them to: (a) deal with the psychic suffering that is mobilized by the reagent result of the anti-HIV test; (b) have the possibility of 
speaking about personal concerns; (c) overcome the difficulties of sharing the news with partners and family members, and (d) dissipate doubts on the prevention of STD and HIV. All of these are components that should be present in the testing and counseling processes in STD/Aids.

\section{References}

Bardin, L. (1995). Análise de conteúdo (L. A. Lopes \& A. Pinheiro, Trans.). Lisboa, Portugal: Edições 70. (Original work published 1977)

Blanchet, A. (1992). L'enquête et les methodes: l'entretien (G. Menezes, Trans.). Paris, France: Nathan.

Filgueiras, S. L., \& Deslandes, S. F. (1999). Avaliação das ações de aconselhamento: Análise de uma perspectiva de prevenção centrada na pessoa. Cadernos de Saúde Pública, 15(2), 121131. Retrieved April 13, 2003, from http://www. scielo.br/scielo.php

Galant, J. E. (2004). HIV counseling, testing and referral. American Family Physician, 70(2), 295302.

Minayo, M. C. S. (1994). O desafio do conhecimento: Pesquisa qualitativa em saúde (3. ed.). São Paulo, SP: Hucitec.

Ministério da Saúde. (1999a). Diretrizes dos Centros de Testagem e Aconselhamento (CTA): Manual. Brasília, DF: Autor.

Ministério da Saúde. (1999b). Aconselhamento em DST, HIV e AIDS: Diretrizes e procedimentos básicos. Brasília, DF: Autor.

Ministério da Saúde. (2010). Diretrizes para organização e funcionamento dos CTA do Brasil. Brasília, DF: Autor.

Miranda, K. C. L., Barroso, M. G. T., Silva, L. M. S. da, \& Silva, M. R. F. da (2008). Reflexões sobre o aconselhamento em HIV/AIDS em uma perspectiva freireana. Revista Brasileira de Enfermagem, 61(6), 899-903.

Moreno, D. M. F. C., \& Reis, A. O. A. (2002). O momento da comunicação do resultado sorológico para o HIV sob a ótica winnicottiana. Pulsional: Revista de Psicanálise, 156, 20-25.

Paiva, V. (1998). O sujeito sexual: Uma proposta de intervenção. Sexualidade, Gênero e Sociedade, 1(10), 4-8
Petchesky, R. P. (1999). Direitos sexuais: Um novo conceito na prática política internacional. In $\mathrm{R}$. Barbosa \& R. Parker (Orgs.), Sexualidades pelo avesso: Direitos, identidades e poder (pp. 1538). Rio de Janeiro, RJ: Editora 34.

Queiroz, M. I. P. (1991). Variações sobre a técnica do gravador no registro da informação viva. São Paulo, SP: T. A. Queiroz.

Rogers, C. (1974a). Antigas e novas perspectivas sobre a consulta psicológica e a psicoterapia. In C. Rogers (Org.), Psicoterapia e consulta psicológica (pp. 30-58). Lisboa, Portugal: Moraes.

Rogers, C. (1974b). O lugar da consulta psicológica. In C. Rogers (Org.), Psicoterapia e consulta psicológica (pp. 15-29). Lisboa, Portugal: Moraes.

Souza, V. de, Czeresnia, D., \& Natividade, C. (2008). Aconselhamento na prevenção do HIV: Olhar dos usuários de um centro de testagem. Cadernos de Saúde Pública, 24(7), 1536-1544.

Winnicott, D. W. (1975a). A localização da experiência cultural. In D. W. Winnicott, $O$ brincar $e$ a realidade (pp. 133-145). Rio de Janeiro, RJ: Imago. (Original work published 1967)

Winnicott, D. W. (1975b). O brincar e a realidade. Rio de Janeiro, RJ: Imago. (Original work published 1971)

Winnicott, D. W (1978a). Aspectos clínicos e metapsicológicos da regressão no setting psicanalítico. In D. W. Winnicott, Textos selecionados: Da Pediatria à Psicanálise (pp. 459-481). Rio de Janeiro, RJ: Francisco Alves. (Original work published 1954)

Winnicott, D. W. (1978b). Objetos transicionais e fenômenos transicionais. In D. W. Winnicott, Textos selecionados: Da Pediatria à Psicanálise (pp. 389-408). Rio de Janeiro, RJ: Francisco Alves. (Original work published 1951)

Winnicott, D. W. (1984). Consultas terapêuticas em Psiquiatria Infantil [Therapeutic consultations in child psychiatry] (J. M. X. Cunha, Trans.). Rio de Janeiro, RJ: Imago. (Original work published 1971)

Winnicott, D. W. (1994a). O jogo do rabisco [Squiggle game]. In C. Winnicott, R. Shepherd, \& M. Davis (Orgs.), Explorações psicanalíticas (J. O. A. Abreu, Trans., pp. 230-243). Porto Alegre, RS: Artes Médicas. (Original work published 1968) 
Winnicott, D. W. (1994b). O valor da consulta terapêutica. In C. Winnicott, R. Shepherd, \& M. Davis (Orgs.), Explorações psicanalíticas (J. O. A. Abreu, Trans., pp. 244-248). Porto Alegre, RS: Artes Médicas. (Original work published 1965)

Winnicott, D. W. (1999). O conceito de indivíduo saudável. In D. W. Winnicott, Tudo começa em casa (P. Sandler, Trans., pp. 3-22). São Paulo, SP: Martins Fontes. (Original work published 1967)
Winnicott, D. W. (2001). Holding e interpretação [Holding and interpretation] (S. M. T. M. Barros, Trans., $2^{\text {nd }}$ ed.). São Paulo, SP: Martins Fontes. (Original work published 1986)

Recebido: 18/05/2012

$1^{a}$ revisão: 13/08/2012

$2^{a}$ revisão: $29 / 08 / 2012$

Aceite final: 24/09/2012 